\title{
Chapter 2 \\ Risk and Resilience in Gifted Young People from Low Socio-economic Backgrounds
}

\begin{abstract}
Nadine Ballam
Gifted and talented young people from low socio-economic backgrounds are consistently under-represented in gifted programmes in New Zealand schools. This chapter reports on a qualitative study that explored the lived experiences of 101 gifted New Zealand young people from low socio-economic backgrounds. An overarching question for this study was 'What is it about gifted young people from low socio-economic backgrounds who have achieved to exceptional levels, that has enabled them to do so?' The risk and resilience construct was used as a lens through which to explore their experiences across a range of contexts. These young people reflected on their perceptions of their giftedness and socio-economic circumstances, their childhoods and school experiences, and their home lives. The stories of the participants in this study indicated that there are particular risks associated with both giftedness and low socio-economic status, and contribute to ideas about how these young people might be more effectively supported to develop their potential.
\end{abstract}

\section{$2.1 \quad$ Introduction}

We tend to have a fascination with people who 'defy the odds' to achieve to exceptional levels, and history has produced numerous examples of eminent individuals who have overcome considerable challenges. For example, Steve Jobs, co-founder of Apple, was adopted out as a child and led a modest life before his influential career in the computer industry (Isaacson 2011). J.K. Rowling, author of the famous Harry Potter series, battled depression and was a solo mother with a very limited income before becoming a world-renowned writer (Smith 2001). Perhaps most fascinating about these people though is not necessarily their actual accomplishments, but the stories of their life journeys and heroic battles against adversity. The intrigue in these stories is not so much what people can achieve, but what enables them to do so.

My interest in gifted and talented young people from low socio-economic backgrounds came mostly from my own childhood experience as a high achiever growing up in a single parent, low-income household. On reflection, I recognised that having high abilities and living with financial constraints had influenced the way my life had unfolded, and this prompted my interest in the 
experiences of others from similar backgrounds. My sense of social justice is also strong, and I have often been an avid supporter of 'the underdog' (which at times has got me into trouble!). In the world of education, 'underdogs' include children and young people who are referred to as 'at-risk'. For my doctoral research, I wanted to explore the intersection of risk (in this case, low socioeconomic circumstances) and giftedness. How do young people who experience both risk and giftedness negotiate this? And what is it that enables some gifted young people from low socio-economic backgrounds to defy statistical odds and achieve to exceptional levels?

Gifted and talented learners from low socio-economic backgrounds are one group who are consistently under-represented in gifted programmes in New Zealand schools (Ministry of Education 2012) and there have been calls for further investigation in this area (Biddulph et al. 2003; Ministry of Education 2008a; Riley 2004). The doctoral research presented in this chapter explored the lived experiences of gifted and talented New Zealand young people from low socio-economic backgrounds in an attempt to gain some understanding of what it might mean for them to be exceptionally competent and living in financially challenging circumstances.

\section{$2.2 \quad$ Literature Review}

To fit the scope of this chapter, general literature about the history of giftedness and talent development, and how our conceptions of these have changed over time, will not be included here. However, readers can follow up on this information in the original thesis (Ballam 2013) or in other sources (e.g., Clark 2013; Shavinina 2009). Here, a brief outline of New Zealand's approach to gifted education and socio-economic climate is provided, followed by some common 'threads' found in studies of gifted and talented individuals from low socio-economic backgrounds. The risk and resilience construct is also examined, and this provides a framework through which both giftedness and socioeconomic circumstances can be explored.

\subsubsection{Gifted Education in New Zealand}

One of the earliest and most influential researchers in the field of gifted education in New Zealand was George Parkyn (1910-1993), who carried out the country's first study on 10 and 11 year old children with IQs of 125 and above (Parkyn 1948). Much like other researchers around this time, Parkyn began his exploration of giftedness with a focus on IQ, however in later years he became an advocate for a broader multicategory concept of giftedness in New Zealand (McAlpine 2005). His findings were published in his book, Children of High 
Intelligence: A New Zealand Study, and this set the scene for a later surge in interest in gifted education in New Zealand.

Moltzen (2011) provided an overview of developments in gifted education in New Zealand since Parkyn's (1948) research, beginning with an increased interest in gifted children around the 1950s. It was during this decade that the first national professional development for educators with an interest in gifted education was held. Renewed interest resulted in a focus on the identification and nurturing of gifted learners, and saw existing notions of intelligence being challenged. According to Moltzen, unfortunately, the Department of Education at the time did not believe it necessary to provide official direction for the education of gifted children and this was left largely to the discretion of individual schools and teachers.

Moltzen (2011) describes the 1970s as a "relatively uneventful era in relation to the gifted in New Zealand” (p. 7), however by the 1980s, international conceptions of giftedness were reflecting a more multicategorical approach (i.e., that gifted students are not solely those with high academic intelligence) and New Zealand followed suit. This multicategorical approach has continued through to more recent Ministry of Education (2000, 2012) documents. Multicategorical approaches reflect a much broader range of talent areas and have the scope to encompass the unique characteristics of a multicultural society, which is particularly important for gifted Māori and Pasifika and other minority cultures in the New Zealand context.

During the 2000s there was a significant increase in research and other initiatives related to gifted education in New Zealand (Moltzen 2011). These included the recognition of special abilities in national education policies (Ministry of Education 2008b) and the development of guidelines for schools, educators, parents, and gifted students (Ministry of Education 2000, 2008c, 2012). However, official support for gifted education has recently waned, with much of the momentum currently coming from professional organisations such as giftEDnz: The Professional Association for Gifted Education (www.giftednz.org.nz), The New Zealand Association for Gifted Children (NZAGC) (www.giftedchildren.org.nz), and The New Zealand Centre for Gifted Education (NZCGE) (www.nzcge.co.nz). Dedicated non-profit groups, individual schools and educators around New Zealand also continue to contribute admirably in local and regional areas.

\subsubsection{New Zealand's Socio-economic Climate}

At the time my doctoral thesis was submitted (early 2013), New Zealand's socio-economic 'landscape' was receiving a lot of attention. The 'gap' between rich and poor was widening (Ministry of Social Development 2010) and rates 
of child poverty ${ }^{1}$ were high, with around $25 \%$ of all New Zealand children reported to be living in poverty (O'Brien et al. 2011; Office of the Children's Commissioner [OCC] 2012).

Since then, child poverty rates have continued to climb, with latest reported figures estimating that $28 \%$ of New Zealand children currently live in households with low incomes, and $8 \%$ are living in low income households (or are homeless) and going without necessities such as food and clothing (Simpson et al. 2016). Children most vulnerable to these statistics are Māori and Pasifika, children living in single parent families and those whose caregivers are dependent on government benefits (Boston 2014; Organisation for Economic Cooperation and Development [OECD] 2015; Perry 2014; Simpson et. al 2016).

The effects of poverty on people and nations around the world have been documented widely (e.g., Carroll et al. 2011; OECD 2015; Wilkinson and Pickett 2010) and child poverty rates in New Zealand are high in comparison to other OECD countries (O'Brien et al. 2011). Of most concern is that the effects of poverty tend to be cumulative and endure into adulthood (EAG 2012; Gibb et al. 2012; Wynd 2011). Young people living in poverty in New Zealand today typically have a lower life expectancy and are more likely to smoke, to be obese, and to indulge in hazardous drinking (Ministry of Social Development 2010). Their health is likely to be affected by a lack of essentials such as food, clothing, and warmth (Egan-Bitran 2010). They are more likely to live in sole parent families, in crowded or low quality housing, or to be transient, which influences their ability to make friends (Ministry of Social Development 2010). These young people are also less likely to have attended early childhood education and are more likely to leave school with few qualifications (Boston 2014; EAG 2013; Perry 2014; Simpson et al. 2016), and this is particularly so for Māori and Pasifika young people (Wynd 2011). The depth, persistence and timing of poverty makes a difference to outcomes (Burney and Beilke 2008; Fletcher and Dwyer 2008; Gunasekara and Carter 2012; St. John and Wynd, 2008).

\subsubsection{Gifted Individuals from Low Socio-economic Backgrounds}

There has been limited research undertaken in New Zealand that specifically relates to gifted and talented young people from low socio-economic backgrounds. Internationally, there is more research focused on this group, much of which derives from the United States. Of these studies, there are few that have

${ }^{1}$ While New Zealand does not have an official poverty measure, a measure for poverty commonly used in official reports in New Zealand is a household equivalent disposable income set at $60 \%$ of the median, after adjusting for housing costs (Boston 2014; Simpson et. al 2016). 
closely examined personal and environmental factors that contribute to or limit achievement and talent development. However, a review of these studies indicated five key personal and environmental elements that were found to be common among gifted individuals from low socio-economic backgrounds.

\subsubsection{Self-concept}

In the studies reviewed, gifted individuals from low socio-economic backgrounds were reported to have generally high self-concepts (Borland et al. 2000; Davidson and Greenberg 1967; Morales 2010; Prom-Jackson et al. 1987; Reis et al. 2005; VanTassel-Baska 1989). Self-concept can be seen as a way of perceiving oneself, or a global evaluation of oneself and, in these studies, this encompassed aspects such as self-esteem, self-worth, and identity.

While there were no clear explanations given as to why these individuals had generally high self-concepts, one point to note is that the participants in these studies tended to have a strong internal locus of control (e.g., Morales 2010; Prom-Jackson et al. 1987) and were inclined to view their successes and failures as related to internal rather than external factors. An individual with a strong internal locus of control feels responsible for his or her successes and is likely to use failures constructively (Davis et al. 2011). These ideas link closely with Dweck's (2000) beliefs, that those who consider intelligence to be 'fixed' (or unable to be changed) are vulnerable to lower self-esteem. In this instance, there is generally an "overconcern with looking smart, a distaste for challenge, and a decreased ability to cope with setbacks" (p. 3). In contrast, the view that intelligence is malleable promotes high self-esteem, as the individual believes that their efforts to learn new things will result in development or mastery of skills and knowledge.

\subsubsection{Drive}

Drive featured strongly as a common personal characteristic in the studies reviewed about gifted individuals from low socio-economic backgrounds, with participants described as having high aspirations (Borland et al. 2000; Morales 2010), strong work ethics (Davidson and Greenberg 1967; Morales 2010), perseverance (Morales 2010; Prom-Jackson et al. 1987), striving to achieve (Davidson and Greenberg 1967), and taking responsibility for their own learning (Davidson and Greenberg 1967; Reis et al. 2005; Stewart and Porath 1999; VanTassel-Baska 1989). Embedded in many of these terms is an implied deliberate effort on the part of these gifted participants, however, a number of eminent individuals are unsure about what the source of their drive actually is. Some describe having an 'inner drive', which might suggest that there is something innate about their capacity to spend large amounts of time and energy on their areas of passion. 
According to Gottfried and Gottfried (2004), drive has been described in gifted literature as a "prerequisite for, component of, catalyst of, and even an outcome of giftedness" (p.121). These authors contend that gifted young people demonstrate considerably higher intrinsic motivation, superior persistence and more focused attention, but that aspects of the environment also play a pivotal role. This complexity of interaction between personal and environmental elements might explain why it is so difficult to ascertain what the source of drive is for many gifted and talented individuals.

\subsubsection{Relationships}

Most of the studies reviewed reported that relationships with parents were a strong influence on positive outcomes for these gifted individuals from low socio-economic backgrounds (e.g., Morales 2010; Prom-Jackson et al., 1987; Shumow 1997; Stewart and Porath 1999; VanTassel-Baska 1989). Morales (2010) found that the parents of his participants tended to be more explicit about wanting to see their children succeed.

The importance of relationships outside of the home, for example, with teachers, coaches and mentors, was evident in these studies also. These relationships reportedly helped participants to 'bridge the gap' between their low socio-economic home environments and other contexts (Morales 2010). People outside of the home context who were influential in these gifted individuals' lives acknowledged their interests and aspirations, encouraged broader perspectives, and provided opportunities that might not be offered in their low socioeconomic home or neighbourhood environments.

\subsubsection{Home environments}

The home environments of the gifted individuals in the studies reviewed tended to be characterised by order and structure (Davidson and Greenberg 1967; Stewart and Porath 1999), despite the challenges associated with low socioeconomic circumstances (Stewart and Porath 1989; VanTassel-Baska 1989). Another element that appeared common to home environments across these studies was a general motivation and stimulation to learn. Shumow (1997) found that participants and their families spent time together engaged in a range of activities. Frierson's (1965) participants were more inclined to engage in competitive activities, play musical instruments, and be more creative in their game playing.

Families of the young people represented in these studies also tended to hold strong values associated with education and work (VanTassel-Baska 1989), and this work ethic was sometimes related to the family view that their challenging socio-economic circumstances should be a motivation to succeed. The high achievers in these studies were typically given responsibilities at a 
young age (Stewart and Porath 1999). Parents held high expectations for their children (Prom-Jackson et al. 1987) and took a keen interest in their education (Davidson and Greenberg 1967), characteristics that are perhaps not stereotypically expected in low socio-economic households.

\subsubsection{Education}

Relationships with supportive teachers who held high expectations for their students were reported in the studies as being important for the development of talent in these gifted young people. Opportunities for extension or development within school contexts were also reported as significant (e.g., Reis et al. 2005; Shumow 1997; VanTassel-Baska 1989), and this may be because of the limited finances or resources available in the home environments of the gifted young people in these studies.

Other elements that were common among these studies in terms of the participants' education included having a range of activities that broadened their learning experiences, having enriched learning activities that were appropriately challenging and intellectually stimulating, and having exposure to extracurricular activities (Borland et al. 2000; Reis et al. 2005). The use of nontraditional identification tools factored in a number of these studies as capturing a broader range of abilities and a more diverse group of potentially talented students (Borland et al. 2000). Consistent with other gifted and talented research, many of these young people thrived when given the opportunity to work closely with likeminded peers (Reis et al. 2005).

\subsubsection{Risk and Resilience in gifted young people from low socio-economic backgrounds}

Resilience is conceptualised as manifested competence in the face of adversity or significant challenges to development (Masten and Coatsworth 1998). This term infers two fundamental judgments; first, that there is currently or has been in the past significant risk or adversity to overcome and, second, that the individual has adapted positively. The definition or measurement of resilience is dependent on evidence of these two dimensions in a person's life.

The resilience construct is comprehensive but, in general terms, resilience is developed as a result of the complex interactions of risk and protective factors and processes. Risk factors encompass the elements that drive an individual towards a less productive outcome, while protective factors move the individual towards adaptive outcomes (Masten 2002). Each factor on its own can influence an individual, but it is the complex process of interaction between risk and protective factors that builds resilience. 
Pfeiffer and Stocking (2000) outline five specific risk factors that relate to academically gifted young people (see Table 2.1).

Table 2.1 Risk factors common to gifted and talented young people

\footnotetext{
Uneven or asynchronous development

Unrealistic expectations of parents, teachers, and significant others

Parental over-involvement or enmeshment

Mismatch between capabilities and the instructional environment

Social and emotional issues resulting from difficulties with the peer group
}

(Pfeiffer and Stocking 2000)

Mueller (2009) suggests that there are two contrasting perspectives relating to the resilience of gifted young people. The first view is that some of the potential characteristics of their giftedness (for example, perfectionism or oversensitivity) may lead to young people being at risk for psychosocial adjustment issues, such as those proposed by Pfeiffer and Stocking (2000). The second argument is that their giftedness acts as a protective factor because of the additional resources available to them (for example, higher levels of confidence in their abilities or optimism).

Resilience literature consistently reports that conditions associated with poverty are a significant risk factor (Gallagher 2008; Pianta and Walsh 1998; Pungello et al. 1996; Schoon et al. 2004) and that resources that come with giftedness are a major protective factor (Bland and Sowa 1994; Masten and Coatsworth 1998; Werner 2000). When personal or environmental features related to poverty pose a risk to positive outcomes for the individual, intellect, gifts, and talents can serve as protective factors that counteract the likelihood of maladaptive outcomes (Seeley 2003).

This connection may appear simplistic, however Harvey and Delfabbro (2004) remind us that the relationship is much more complex. Young people raised in low socio-economic households are more likely to experience other risk factors in addition to poverty (Evans 2004; Pungello et al. 1996; Rutter 2007). For example, a high level of stress in the home is one risk factor associated with socio-economic disadvantage, and this can have long lasting effects on individuals (Luthar 2006).

Not all gifted young people from low socio-economic backgrounds flounder and there are numerous examples of highly successful gifted adults who have come from disadvantaged backgrounds. According to Rutter (2007), for some of these individuals, the experience of adversity may present particular opportunities that actually promote resilience. The interrelatedness of environmental, biological and intrapersonal influences, and risk and protective processes in the lives of individuals from low socio-economic backgrounds has a direct impact on whether or not their gifts and talents are realised. 


\subsection{Methodology}

As noted earlier, my aim for this study was to explore the lived experiences of gifted and talented New Zealand young people from low socio-economic backgrounds. The research questions for this study were:

1. What perceptions, evaluations, and attributions do the participants hold in relation to their gifts and their socio-economic status?

2. What are the personal and environmental features present in the lives of the participants that they consider have enabled them to achieve significantly in their area/s of giftedness or talent?

3. What are the personal and environmental features present in the lives of the participants that they believe have the potential to restrict the development of their gifts and talents?

4. What is the nature of the interactions between personal and environmental features and how do these interactions impact on the development of the participants' gifts and talents?

5. How have the participants' gifts and talents functioned as protective factors, contributed to resilience, or led to vulnerability?

6. How might risk and protective factors related to the participants' personal and environmental experiences be minimalised or capitalised on in order to develop resilience?

\subsubsection{Interpretative Phenomenological Analysis}

A qualitative approach was considered most appropriate to address the research questions, as this is particularly useful for the investigation of complex topics such as giftedness and risk and resilience, where understanding interactive processes is the concern. Yardley (2008) outlines that qualitative research is sensitive to culture and context, and New Zealand's unique cultural context was important to consider in this study.

The qualitative methodology selected for this study was Interpretative Phenomenological Analysis (IPA), which involves detailed investigation of lived experiences and how individuals make meaning of these experiences (Eatough and Smith 2008). The participant is seen as the "experiential expert" (Smith and Osborn 2008, p. 57) and the researcher is attempting to gain an 'inside perspective' of the participant's lifeworld. There are five central characteristics of IPA (Brocki and Wearden 2006; Reid et al. 2005):

1. Phenomenology - clarifying situations as they are directly experienced by individuals in the contexts of their lives (Giorgi and Giorgi 2008).

2. Interpretation - involving a double hermeneutic, where participants are attempting to make sense of their world, and the researcher is "trying 
to make sense of the participants trying to make sense of their world" (Smith and Osborn 2008, p. 53).

3. Idiography - preserving the distinctive features of the individual cases (Smith and Dunworth 2003).

4. Cognition - emphasising the beliefs, attitudes, and thought processes associated with experiences rather than just the factors of the experi ence itself (Smith and Osborn 2008).

5. The individual case - giving full attention to an individual case be fore moving on to the next case or attempting to analyse across cases (Giorgi and Giorgi 2003).

\subsubsection{Theoretical Frameworks}

Along with the risk and resilience construct outlined earlier, Bronfenbrenner's $(1979,2005)$ (bio)ecological systems theory was used as a theoretical framework to examine the interactions and resources that existed in the participants' environments that influenced their potential for gifted achievement. Both giftedness and poverty have been linked with ecological theories of development (Bloom 1985; Burney and Beilke 2008; Coleman 2006; Piirto 2007; Simonton 2005). Writers in the area of giftedness and talent (e.g., Gagné 2003; Renzulli 2002; Tannenbaum 2003) have argued that key ingredients for the realisation of exceptional potential lie within individuals and their environments, and the interactions that occur between both. Socio-economic circumstances can influence the nature and quality of interactions that occur within and between the environments of gifted individuals.

\subsubsection{Participants}

A difficulty associated with research with gifted young people from low socioeconomic backgrounds is their under-representation in gifted and talented programmes, and sourcing participants for this study proved challenging. Fortunately, I stumbled across a New Zealand organisation, First Foundation (http://www.firstfoundation.org.nz), which awards scholarships to talented young New Zealanders from financially disadvantaged backgrounds. Students from low decile ${ }^{2}$ schools are invited to apply for the scholarships once they

\footnotetext{
${ }^{2}$ A school's decile rating indicates the proportion of its students that come from low socio-economic communities (Ministry of Education 2008b). Schools are ranked from decile 1 to decile 10 , with decile 1 schools drawing the highest proportion of students from low socio-economic communities. At the time of writing, a proposal has been made by the New Zealand government to remove the decile rating system in New Zealand in favour of another school funding mechanism.
} 
reach Year 12 (the second to last year of secondary school in New Zealand). The advantage of recruiting participants from First Foundation was that these young people had met already established criteria for giftedness and talent in a range of areas, and also socio-economic disadvantage.

The first phase of the study involved an online survey which was distributed to the existing database of 181 past and present First Foundation scholarship recipients. Of these, 93 responded, and Table 2.2 outlines some demographic characteristics of this group.

Table 2.2 Demographic details of online survey participants

\begin{tabular}{ccccc}
\hline $\begin{array}{c}\text { Survey } \\
\text { participants }\end{array}$ & Age group & Gender & Ethnicity & Talent area \\
\hline $\mathrm{n}=93$ & $<17 \mathrm{yrs}=1$ & $\mathrm{M}=26$ & NZ Māori $=15$ & Academic $=66$ \\
& $17-21 \mathrm{yrs}=73$ & $\mathrm{~F}=67$ & NZ European $=38$ & Leadership $=55$ \\
$22-25 \mathrm{yrs}=15$ & & Pasifika $=29^{3}$ & Creative Arts $=27$ \\
& $>25 \mathrm{yrs}=4$ & & Other $=41^{4}$ & Sports $=23$ \\
& & & & Other $=4^{5}$ \\
\hline
\end{tabular}

For the second phase of the research, eight past or present scholarship recipients, representing a range of talent areas, ethnicities and gender, were invited to take part in semi-structured interviews. Demographic characteristics for these interview participants are outlined in Table 2.3.

Table 2.3 Demographic details of interview participants

\begin{tabular}{ccccc}
\hline $\begin{array}{c}\text { Interview } \\
\text { participants } \\
\text { (pseudonyms) }\end{array}$ & $\begin{array}{c}\text { Age } \\
\text { (at time } \\
\text { of } \\
\text { interview) }\end{array}$ & Gender & Ethnicity & Major talent area \\
\hline Laura & 22 & $\mathrm{~F}$ & European & Creative arts (visual) \\
Kris & 20 & $\mathrm{M}$ & Māori/European & Sport \\
Ben & 19 & $\mathrm{M}$ & Samoan & All rounder \\
Jennae & 22 & $\mathrm{~F}$ & European & Creative arts (dance) \\
Niu & 22 & $\mathrm{M}$ & Niuean/European & Sport \\
Sarah & 17 & $\mathrm{~F}$ & Chinese/Cambodian & Academic \\
Matiu & 22 & $\mathrm{M}$ & Māori/Cook Islander & Leadership \\
Aroha & 18 & $\mathrm{~F}$ & Māori & Leadership \\
\hline
\end{tabular}

\footnotetext{
${ }^{3}$ A number of Pacific nations were represented in the survey, predominantly by Samoan, Tongan, Cook Island, Fijian, and Niuean individuals.

${ }^{4}$ The discrepancy in numbers here reflects the opportunity for participants to select all ethnicities that they identified with. Other ethnicities represented amongst survey participants included Indian, Chinese, Vietnamese, Australian, and Latin American.

${ }^{5}$ Participants were also able to nominate more than one area of talent if this was applicable. The total number of responses here indicates that most participants selected more than one talent area.
} 


\subsubsection{Data collection and analysis}

The online survey gathered a broad picture of the experiences of gifted and talented young people from low socio-economic backgrounds in relation to:

- their personal characteristics

- their gifts and talents

- their childhood and school experiences

- their families, peers, and role models

- their socio-economic circumstances

The interviews elicited more in depth information in relation to these five categories. Interview participants were also encouraged to have ongoing email contact with me, to add to or clarify anything they had said. A third phase of the research involved collecting additional data from the eight interview participants' scholarship application files (for example, school records and referee reports), to verify the participants' verbal accounts.

The online survey responses were analysed using the online survey reporting programme and any qualitative responses or additional comments were manually analysed for emerging themes. The interviews were transcribed soon after they took place, and participants were encouraged to read and amend these as they felt appropriate. An advantage of IPA is that there are detailed procedural guides for the analysis of data (Brocki and Wearden 2006; Smith 2004), which provide a systematic guide to this process. This analytic process pays attention to the participants' verbal accounts, the type of language used, body language, and any other observations the researcher makes (Smith and Osborn 2008).

\subsection{Findings and Discussion}

Three overarching themes emerged from the data, and these were 'Identity', 'Drive' and 'Opportunities'. Each of these themes presented key findings related to risk and resilience processes among the group of gifted young people in this study. These key findings were:

- Identity - giftedness generally presented more risks to these young people's sense of identity than socio-economic circumstances.

- Drive - the most common source of drive for these young people was the desire to change their personal circumstances and to 'give back' or be role models for others.

- $\quad$ Opportunities - the most valuable opportunities for these young people were relational, more so than material. 


\subsubsection{Identity}

One of the more significant and surprising findings in this study was that the limitations associated with being gifted appeared to present as more of a risk to the participants' sense of identity than the constraints of their socio-economic circumstances. This stands in stark contrast with much of the resilience literature and research, which largely reports that giftedness works as more of a protective factor and that poverty generally puts people more at risk of negative outcomes (e.g., Bland and Sowa 1994; Gallagher 2008; Masten and Coatsworth 1998; Pianta and Walsh 1998; Pungello et al. 1996; Schoon et al. 2004; Werner 2000). One explanation for this could relate to the participants in this study having recently been awarded scholarships for their high achievements. It is likely that participants viewed their socio-economic circumstances in a more positive light, as there had been some significant benefit for them.

The weight and impact of expectations that came with being gifted was the most common aspect reported by both survey and interview participants to have the greatest influence on their sense of identity. Survey participants were asked to indicate what the worst thing was about being gifted and talented, and approximately $75 \%$ of the respondents referred to the fear of failure or selfdoubt that came as a result of the pressure to perform. This finding is consistent with the ideas of Pfeiffer and Stocking (2000), who proposed that the unrealistic expectations of parents, teachers, and significant others is a risk factor common to gifted young people.

Participants reported that high expectations came from themselves as well as from others. One male survey participant stated, "I am my biggest critic and tend to beat myself up a lot when something doesn't go right.” In his interview, Kris also described having high expectations for himself: "[I] expect a lot from myself and I'm pretty harsh on myself. If I don't achieve what I want to achieve sometimes I get really - not down, but I get sort of angry."

The perceived expectations of other people were also reflected in survey participants' responses, through statements such as: "You feel like a failure if you don't achieve what others expect you to, or if you don't do as well as what you hope. You feel like you are letting people down.” Other comments revealed some of the personal impacts of expectations:

The expectation is the worst thing by far. People think that you're perfect all the time and therefore when you do make a mistake, they fall on top of you like a ton of bricks. If people are watching your every move it becomes distracting because it feels as if they are waiting for you to slip up and fail. People expect you to be on the ball all of the time.

In contrast, less than a third of survey participants and only four interview participants claimed that socio-economic adversity and associated challenges had negatively impacted on their sense of identity. Instead, approximately 75\% of participants reported that their low socio-economic circumstances had actually had a positive influence on their sense of identity. These benefits included 
elevated motivation and determination, the development of strong work ethics and an appreciation for things that other young people perhaps did not place as much value on. One survey participant described how low socio-economic circumstances had heightened her self-awareness:

[Financial constraints] made me appreciate things more and place more value on simple things, taught me the value of hard work, [and] taught me that it is never a reason for failure, because success does not stem from money but from other values, all of which do not have a dollar value.

Others talked about how financial constraints had made them "realise the value of a well earned dollar" and given them the sense of contributing to their own successes without having "everything handed to me on a silver platter."

The finding presented here does not suggest that all young people who grow up in low socio-economic circumstances inevitably develop high levels of motivation and strong work ethics, or achieve great things; nor does this imply that young people from low socio-economic backgrounds should be left to face challenges without support or intervention. Almost $70 \%$ of survey respondents and all eight interviewees made it clear that their socio-economic circumstances were definitely limiting in relation to their talent development, although they mostly attributed this to material resources (what they had or didn't have) rather than identity (who they were). A positive implication from this finding is that low socio-economic circumstances do not automatically assume maladaptive outcomes and these can instead be a key catalyst for resilience and positive outcomes in later life.

It would also be premature to claim that only those with a strong sense of identity go on to achieve to high levels, as self-concept is changeable across time and context. Literature related to high achievers readily identifies the social and emotional struggles that many gifted individuals grapple with (Clark 2013; Galbraith and Delisle 2015; Neihart et al. 2002) and the young people in this study also spoke extensively about times of self-doubt and low confidence. One implication here is the need to carefully balance the provision of or exposure to challenge with appropriate performance expectations. There is clearly a fine line between these and not achieving this balance could mean the difference between wellbeing and underachievement.

The finding that giftedness might act as more of a risk factor for individuals than low socio-economic circumstances does not necessarily contradict ideas presented in resilience literature, but rather adds to these. Luthar's (1991) research is one of few studies that found high intelligence to be working as a risk factor for her participants. It would be tenuous to claim that having high abilities inevitably puts gifted young people 'at-risk'; rather, the interaction between giftedness and identity is far more complex than this and factors that are unique to the contexts of each gifted individual's life can alter these effects. However, the notion that particular elements of their giftedness might exacerbate risk amongst particular groups would be interesting to explore further. 


\subsubsection{Drive}

Drive has been noted by researchers to be a recurrent theme in the studies of gifted individuals over the years (e.g., Bloom 1985; Cox 1926; Moltzen 2005; Morales 2010; VanTassel-Baska 1989), and this study was no exception. While drive has been described in a number of ways, there is general understanding that this characteristic refers to the heightened energy or momentum of many gifted individuals. What is usually not clear is what creates or causes this intense determination, however, a significant number of participants in this study reported that they were predominantly driven by a desire to change their personal circumstances and to 'give back' or be a role model for others.

While some of the participants in this study actually used the word 'drive' in their responses, they also described this characteristic as a "fuelled desire" or a "driving force", something that made them highly motivated, focused, and perseverant. Others talked about being strong-willed, stubborn, single-minded, and passionate. One young man stated that he would "go all out" to achieve, a sentiment shared by many other participants who referred to the strong work ethic they had developed as a result of their ambition or will to succeed.

Participants were asked to describe how they felt their socio-economic circumstances had contributed to the development of their gifts and talents, and half of the respondents to this question described having an intense drive brought about by a strong resolve to change their personal circumstances:

When you're surrounded by a less than positive environment and characterised by negative stereotypes, there's no shortage of motivation to better yourself by developing your talents or skills to break the mould and defy those narrow minded views.

I've seen the good side and bad side of New Zealand society. I made a decision early on that I was not going to follow the path of negativity. I want to 'get out of the gutter', so to speak. This burning desire to get out has helped me develop my gifts or talents.

Six of the eight interview participants talked at length about their determination to change their personal circumstances. Both Laura and Sarah indicated that they did not want their lives to replicate those of their parents', and that this had driven them to work hard. Of the financial challenges her family had faced, Laura said:

I think it just encouraged me to work harder for the things that I wanted ...I want more - not that I think badly of what my parents have or anything like that but I want more and I aspire to more....

Aroha's upbringing, much like Matiu's, was characterised by unemployment, substance abuse and violence, and they described their families as being caught in a "poverty cycle." Matiu's determination to break out of the cycle his extended family had lived in for years had developed at a young age: 
From the beginning I knew [what] I wanted to be, you know, and I put it in my head from a young age that it didn’t matter what I wanted to be, I [knew] I didn’t want to be that.

Aroha and Matiu's comments were typical of many of the young people in this study, whose drive to change their own circumstances also extended to a desire to impact the lives of their families and others. Aroha reflected that "being in that environment sort of makes me angry and upset that that's the way we have to live, and that became my motivation and my inspiration.” She went on to say:

... I'm out here busting it every day trying to prove to them that there's something more - you know, trying to break that chain of unemployment around my family ...I want to be the first to sort of break through the ice, and then make a path for them so that, yeah - they live a good life instead of having to struggle.

There are few other studies that indicate a direct association between high levels of drive and a resolve to improve socio-economic circumstances, however, research does indicate that a significant proportion of eminent individuals experienced challenges throughout their childhoods (e.g., Goertzel and Goertzel 1962; Moltzen 2005; Roe 1952). The idea that adversity might contribute to a high level of drive is also discussed in resilience literature (e.g., Werner 1993; Werner and Smith 1982). In his work with academically successful young people from low socio-economic backgrounds, Morales (2010) found that a strong desire to change their personal circumstances was a key protective factor for almost all of his 50 participants. What is relevant to consider here is how other gifted young people might be explicitly empowered to manage similarly adverse situations. It would be reasonable to propose that an element of challenge can be a catalyst for effort if there is sufficient reason to confront a particular challenge.

The idea that socio-economic adversity ranks strongly as a source of drive for gifted individuals from financially challenging backgrounds provides an interesting point for further study. With rates of child poverty in New Zealand increasing (Simpson et al. 2016), the relationship between socio-economic circumstances and educational achievement is progressively becoming an important area of focus. Future studies could provide further insight into the complex interrelationship of exceptional ability and poverty.

\subsubsection{Opportunities}

It became apparent through the stories of the young people in this study that people-related opportunities were considerably more important to them than material opportunities (for example, funding or material resources). Almost all participants spoke extensively about the significance of role models, mentors, and other social supports present in their homes, schools and communities. This 
was predominantly because strong relationships with others not only provided support and encouragement, but also offered crucial access to additional opportunities and networks. From their stories, it was evident that it was not the quantity of opportunities these young people received that was important; rather, it was the type of opportunity that appeared to make a difference.

In this study, $82 \%$ of survey participants indicated that the most significant opportunity in their home environments came in the form of supportive relationships with family members, mainly their parents. One survey participant stated, "They have always pushed me to join lots of sports teams and always taken an interest in my homework and have always been so supportive, and this has boosted my confidence.” All of the eight interview participants considered that their parents had provided a range of opportunities for them and mothers tended to be mentioned more often than fathers. Ben described his mother as being a source of support because she was "always consistent" with her "straight up, candid comments and encouragement." Niu also acknowledged his mother as having been the "biggest influence" in his life and he stated that she did her best to support him to get involved in various activities, despite financial challenges.

The fact that relationships with significant others in the home environment made such a difference in the lives of the young people in this study contrasts with assumptions that might exist about low socio-economic households. Literature related to poverty tends to report the less desirable aspects of living in low socio-economic circumstances and there is little doubt that the circumstances of the young people in this study afforded them fewer assets or advantages. However, consistent with other studies of gifted individuals from low socioeconomic backgrounds (e.g., Bloom 1985; Shumow 1997; VanTassel-Baska 1989), the parents of many of these young people generally valued education and achievement and also tended to expose their children to a range of environments and activities, giving them a broader perspective of options available to them. Parents who optimise interactions with their children can compensate for a lack of financial or other resources (Biddulph et al. 2003), and this was certainly the case for participants like Kris, who spoke appreciatively of stimulating family discussions and learning experiences in his home. According to Masten and Obradovic (2006), these are also aspects of family life that play a crucial role in resilience.

In the school setting, supportive relationships with teachers were cited by both survey respondents and interviewees as being valuable, as these often resulted in access to further opportunities. Individual teachers who had provided participants with opportunities to develop were fondly identified by name by several of the young people in this study, and some described how their secondary school teachers in particular had spent many hours of their own time helping them to develop their potential. Niu talked about his relationship with a teacher who became like "an honorary grandparent” through her ongoing support of him and his family, and this relationship continued after he left the school. Sarah had one particular teacher who she described as having "always been there as - like a back board, showing me ideas and stuff like that.” Other 
teachers saw that participants were extended by enrolling them in university papers if appropriate and spending time preparing them for extracurricular exams. Some teachers went so far as to fund or subsidise sports fees for promising athletes.

Of course, not all of the young people in this study had good relationships with their teachers and, to the same extent that positive relationships were fundamental in terms of their talent development, less supportive relationships with teachers appeared to have quite a damaging effect. One survey respondent commented that her opportunities had been limited by "teachers who do not want to take or make the time to push you beyond your boundaries and like to play it safe and hug the status quo." Another young woman pointed out that she would always "get left to 'work independently' during class" because she was considered capable.

The importance of relationships with parents, teachers, and other adult role models has also been extensively highlighted in both gifted (e.g., Clasen and Clasen 1997; Moltzen 2005; Parkyn 1948) and resilience research (Masten and Coatsworth 1998; Rutter 1987). This study confirms that strong, supportive relationships with other people are crucial for enabling the talent development process and, according to the accounts of these young people, this is primarily because it is other people who can facilitate access to further developmental opportunities. According to Katz (1997), numerous meaningful opportunities are the key to developing resilience, and these provide the chance for young people such as those in this study to find their way out of circumstances that potentially put them at risk.

\subsubsection{Pathways to Resilience}

The findings from this and earlier studies leave little doubt that being gifted can be advantageous. However, giftedness can also come at a price, and some of the studies reviewed earlier in this chapter indicate that high achievers sometimes contend with challenges that less able people may not necessarily face. The additional challenge for the group of young people in the study reported here was their low socio-economic circumstances, and the majority could clearly articulate how financial adversity had influenced their talent development in a number of ways.

Current understandings of resilience emphasise the processes associated with positive adaptation rather than resilience as a fixed trait, and the intricate connections between the key elements that emerged from this study add to contemporary ideas about how gifted young people might positively adapt in adverse circumstances. The model that follows (see Figure 2.1) indicates personal and environmental risk and protective factors that emerged as strongest for the gifted young people in this study across some of the key contexts of their lives. What became apparent in the participants' stories was that there were several 
connections between these factors, and an attempt has been made here to illustrate some of the processes involved in the development of resilience also.

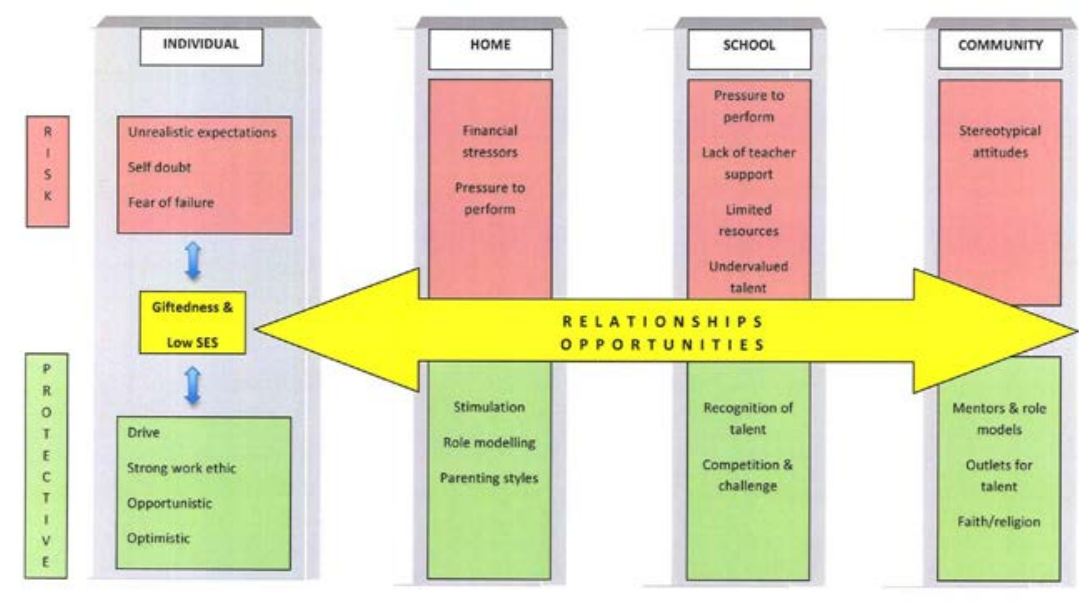

Fig. 2.1 Resilience model for gifted and talented young people from low socio-economic backgrounds

As indicated in this model, giftedness and low socio-economic status generated two risk and protective processes that occurred across all contexts of these gifted young people's lives. These were relationships and opportunities, both of which are discussed widely in other studies of gifted and resilient people (Clasen and Clasen 1997; Masten and Coatsworth 1998; Moltzen 2005; Parkyn 1948; Rutter 1987). These two processes were closely linked; while relationships were clearly important, it was the opportunities that came with these relationships that appeared necessary for these young people to thrive. For these young people, relationships generated access to additional opportunities, which exposed them to broader social interactions, and these in turn offered further opportunities.

A number of risk and protective factors that were not highlighted in the three key findings reported earlier are evident in this model also. ${ }^{6}$ One protective factor common amongst the young people in this study was their opportunistic natures. It became increasingly evident through interactions with the participants that these young people were largely opportunistic and that some of their successes could be attributed to the ability to seek out, recognise, and

${ }^{6}$ For a more extensive discussion of the risk and protective factors and processes identified in this model, please see the original thesis (Ballam 2013). 
capitalise on opportunities that came their way. Laura stated that she had a “tendency to rely on myself to make things happen. I don't want to sit and wait for the world to approach me. It's not very often that fate falls out of the sky and lands on your lap.” Ben said:

Unless you go out there and do it for yourself, it's not going to happen, but hey, that's the name of the game - shape up or ship out. If you're out in the forest and you're alone and you're hungry, no one's going to fly in Air New Zealand and say 'Here's a three course meal.' You've got to go out and fend for yourself.

In the home context, parenting styles were mentioned as having influenced levels of drive and, consequently, achievements. Sarah explained that her mother "never settles for second best", and this constantly pushed her to do better. Kris mentioned that his parents had "always put the onus on us", and that he and his brothers had all been hard on themselves and put in extra effort to get results. Interestingly, a small number of participants in this study who described their relationships with their parents as distant or inconsistent still attributed their strong determination to the influence of their caregivers. For example, Aroha portrayed her relationship with her father as difficult and frequently disappointing, yet she acknowledged this relationship as having a major influence on her talent development.

The element of competition emerged as common among these young people also, particularly in the school context. For example, Kris talked about thriving on the challenge of meeting his personal goals, and that this extended to being competitive with others. He explained, “... in anything, like with my friends, I always try to beat them - not for an egotistical reason, just for the point of proving to myself that I can do it.” Competition has not been widely reported as contributing to drive in other studies with gifted individuals and consequently it would be inappropriate to draw definitive conclusions about the role of this in talent development. However, further exploration into how competition and challenge might contribute to drive amongst gifted young people from low socio-economic backgrounds in particular, would be useful to explore.

In the community setting, associations with churches or other religious groups was an interesting element highlighted among many of these young people's stories. While some participants talked about their personal 'faith' as being a source of hope and personal strength, others felt that being part of a church community had given them opportunities to develop and share their gifts. Masten and Coatsworth (1998) identify faith as an individual characteristic of resilience, and connections to prosocial organisations as a protective factor. Through her resilience research, Werner (1993) discovered that many of those who had emerged successfully from impoverished environments had cited religious faith as being instrumental in them overcoming their circumstances. There is also evidence in other literature of the significance of religion or faith. Masten and Obradovic (2006) identify religion, values, and standards as contributing to adaptive developmental outcomes. 
Over time and as contexts change, risk and protective elements and processes change. While this model may be relevant to the young people in this study at the time this research was undertaken, it would be tenuous to suggest that this combination of risk and protective factors and processes will have similar effects as they grow older and move into different contexts (for example, out of the educational context and into the work force). What this model does offer, however, is a preliminary glimpse at what gifted New Zealand young people from low socio-economic backgrounds had in common that influenced their levels of resilience as they negotiated both their giftedness and low socioeconomic circumstances.

\subsection{Conclusion}

This study is unique in that it is the only New Zealand study so far that has specifically investigated the experiences of gifted young people who have grown up in, or are still experiencing, socio-economic adversity. In a context where poverty rates are increasing (Simpson et al. 2016) and the gap between wealthy and poor continues to widen (Carter et al. 2013), growing numbers of gifted and talented New Zealand young people are likely to face challenges similar to those in this study.

A number of implications arising from this study are mentioned throughout this chapter, along with areas that would be interesting to explore further. One of the biggest limitations of this research is that the participants had already been identified as high achievers and were therefore likely to be having very different experiences to what gifted underachievers from low socioeconomic backgrounds might have. As expressed earlier in this chapter, gifted underachievers are extremely difficult to identify; however, if these difficulties could be overcome, a similar study carried out with gifted underachievers from low socio-economic backgrounds would provide an interesting comparison and extend existing knowledge about the experiences of gifted and talented young people from low socio-economic backgrounds.

It is clear from this study that gifted young people from low socioeconomic backgrounds face definite challenges in relation to developing their gifts and talents. However, there is also evidence that a remarkable number of these young people are resilient; able to overcome adversity and achieve to exceptional levels. In a climate where provisions for gifted and talented learners have been put to the side at an official level, it is crucial that organisations and communities who advocate for these young people maintain momentum. Focusing attention on assisting these young people to develop their own potential, is also devoting attention to New Zealand's capacity to effectively compete and contribute on the global stage. 


\section{References}

Ballam, N. (2013). 'Defying the odds': Gifted and talented young people from low socioeconomic backgrounds. (PhD thesis, University of Waikato, 2013).Retrieved from http://researchcommons. waikato.ac.nz/bitstream/handle/10289/8424/thesis.pdf?se quence $=3 \&$ isAllowed $=\mathrm{y}$

Biddulph, F., Biddulph, J., Biddulph, C. (2003). The complexity of community and family influences on children's achievement in New Zealand: Best evidence synthesis. Wellington, New Zealand: Ministry of Education.

Bland, L. C., \& Sowa, C. J. (1994). An overview of resilience in gifted children. Roeper Review 17(2), 77-80.

Bloom, B. S. (Ed.). (1985). Developing talent in young people. New York: Ballantine Books.

Borland, J. H., Schnur, R., Wright, L. (2000). Economically disadvantaged students in a school for the academically gifted: A postpositivist inquiry into individual and family adjustment. Gifted Child Quarterly, 44(1), 13-32.

Boston, J. (2014). Child poverty in New Zealand: Why it matters and how it can be reduced. Educational Philosophy and Theory, 46(9), 962-988.

Brocki, J. M., \& Wearden, A. J. (2006). A critical evaluation of the use of interpretative phenomenological analysis (IPA) in health psychology. Psychology and Health, 21(1), 87-108.

Bronfenbrenner, U. (1979). The ecology of human development: Experiments by nature and design. Cambridge, MA: Harvard University Press.

Bronfenbrenner, U. (2005). The bioecological theory of human development. In U. Bronfenbrenner (Ed.) Making human beings human (pp.3-15). Thousand Oaks, CA: Sage. (Reprinted from N.J. Smelser \& P.B. Baltes (Eds.), International encyclopaedia of the social and behavioural sciences. (Vol. 10, pp.6963-6970). New York: Elsevier, 2001).

Burney, V. H., \& Beilke, J. R. (2008). The constraints of poverty on high achievement. Journal for the Education of the Gifted, 31(3), 295-321.

Carroll, P., Casswell, S., Huakau, J., Howden-Chapman, P., Perry, P. (2011). The widening gap: Perceptions of poverty and income inequalities and implications for health and social outcomes. Social Policy Journal of New Zealand, 37, 1-12.

Carter, K., Gunasekara, F. I., Blakely, T. (2013). The relationship between trends in income inequalities and poverty in New Zealand. Policy Quarterly, 9(2), 24-29.

Clark, B. (2013). Growing up gifted ( $8^{\text {th }}$ ed.). Upper Saddle River, NJ: Pearson.

Clasen, D. R., \& Clasen, R. E. (1997). Mentoring: A time-honored option for education of the gifted and talented. In N. Colangelo \& G. A. Davis (Eds.), Handbook of gifted education ( $2^{\text {nd }}$ ed., pp.218-229). Boston, MA: Allyn \& Bacon.

Coleman, L. (2006). Talent development in economically disadvantaged populations. Gifted Child Today, 29(2), 22-27.

Cox, C. (1926). The early mental traits of three hundred geniuses. Stanford, CA: Stanford University Press.

Davidson, H. H., \& Greenberg, J. W. (1967). Traits of school achievers from a deprived background. Washington, DC: Department of Health, Education, and Welfare.

Davis, G. A., Rimm, S. B., \& Siegle, D. (2011). Education of the gifted and talented ( $6^{\text {th }}$ ed.) Upper Saddle River, NJ: Pearson.

Dweck, C. S. (2000). Self-theories: Their role in motivation, personality, and development. New York: Taylor \& Francis. 
Eatough, V., \& Smith, J. A. (2008). Interpretative phenomenological analysis. In C. Willig \& W. Stainton-Rogers (Eds.), The Sage handbook of qualitative research in psychology (pp. 179-194). London: Sage.

Egan-Bitran, M. (2010). 'This is how I see it': Children, young people, and young adults' views and experiences of poverty. Wellington, New Zealand: Office of the Children's Commissioner.

Evans, G. W. (2004). The environment of childhood poverty. American Psychologist, 59(2), 77-92.

Expert Advisory Group on Solutions to Child Poverty (2012). Solutions to child poverty in New Zealand: Evidence for action. Wellington: Office of the Children's Commissioner.

Expert Advisory Group on Solutions to Child Poverty (2013). Child poverty in New Zealand: Building on progress to date. Wellington: Office of the Children's Commissioner.

Fletcher, M., \& Dwyer, M. (2008). A fair go for all children: Actions to address child poverty in New Zealand. Wellington, New Zealand: Children's Commissioner.

Frierson, E. C. (1965). Upper and lower status gifted children: A study of differences. Exceptional Children, 32(2), 83-90.

Gagné, F. (2003). Transforming gifts into talents: The DMGT as a developmental theory. In N. Colangelo \& G. A. Davis (Eds.), Handbook of gifted education (3rd ed., pp. 60-74). Boston, MA: Pearson Education.

Galbraith, G. \& Delisle, J. (2015). When gifted kids don't have all the answers: How to meet their social and emotional needs. Minneapolis MN: Free Spirit Publishing.

Gallagher, J. J. (2008). Psychology, psychologists, and gifted students. In S. I. Pfeiffer (Ed.), Handbook of giftedness in children: Psycho-educational theory, research, and best practices (pp.1-11). New York: Springer Science \& Business Media, LLC.

Gibb, S. J., Fergusson, D. M., Horwood, L. J. (2012). Childhood family income and life outcomes in adulthood: Findings from a 30-year longitudinal study in New Zealand. Social Science \& Medicine, 74(12), 1979-1986.

Giorgi, A., \& Giorgi, B. (2008). Phenomenology. In J. A. Smith (Ed.), Qualitative psychology: A practical guide to research methods ( $2^{\text {nd }}$, ed., pp.26-52). London, UK: Sage.

Goertzel, V., \& Goertzel, M. G. (1962). Cradles of eminence. Boston: Little, Brown \& Co.

Gottfried, A. E. \& Gottfried, A. W. (2004). Toward the development of a conceptualisation of gifted motivation. Gifted Child Quarterly, 48(2), 121-132.

Gunasekara, F. I., \& Carter, C. (2012). Dynamics of income in children in New Zealand, 2002-2009: A descriptive analysis of the Survey of Family, Income and Employment. Wellington: Department of Public Health.

Harvey, J., \& Delfabbro, P. H. (2004). Psychological resilience in disadvantaged youth: A critical overview. Australian Psychologist, 39, 3-13.

Hunsaker, S. L., Frasier, M. M., Frank, E., Finley, V., Klekotka, P. (1995). Performance of economically disadvantaged students placed in gifted programmes through the research-based assessment plan. Storrs, CT: The National Research Centre on the Gifted and Talented.

Isaacson, W. (2011). Steve Jobs: The exclusive biography. New York: Simon \& Schuster.

Katz, M. (1997). On playing a poor hand well: Insights from the lives of those who have overcome childhood risks and adversities. New York: Norton. 
Luthar, S. (1991). Vulnerability and resilience: A study of high-risk adolescents. Child Development, 62, 600-616.

Luthar, S.S. (2006). Resilience in development: A synthesis of research across five decades. In D. Cicchetti \& D. J. Cohen (Eds.), Developmental psychopathology, Volume three: Risk, disorder, and adaptation ( $2^{\text {nd }}$ ed., pp.739-795). New York: Wiley.

Masten, A. S. (2002). Ordinary magic: A resilience framework for policy, practice, and prevention. Paper presented at the Conference on Risk and Resilience: Protective Mechanisms and School-Based Prevention Programmes, 25-27 October, 2002, Cambridge, Massachusetts.

Masten, A. S., \& Coatsworth, J. D. (1998). The development of competence in favorable and unfavorable environments: Lessons from research on successful children. American Psychologist, 53, 205-220.

Masten, A. S., \& Obradovic, J. (2006). Competence and resilience in development. Annals of the New York Academy of Sciences, 1094, 13-27.

McAlpine, D. (2005). What do we mean by gifted and talented? Concepts and definitions. In D. McAlpine \& R. Moltzen (Eds.), Gifted and talented: New Zealand perspectives (pp. 33-65). Palmerston North, New Zealand: Kanuka Grove Press.

Ministry of Education. (2000). Gifted and talented students: Meeting their needs in New Zealand schools. Wellington, New Zealand: Learning Media.

Ministry of Education. (2008a). Gifted and talented students: Initiatives for gifted and talented learners. Retrieved from http://www.tki.org.nz/r/gifted/initiatives_e.php

Ministry of Education. (2008b) The National Administration Guidelines (NAGs). Retrieved

from http://www.minedu.govt.nz/educationSectors/Schools/PolicyAndStrategy/Plannin gReportingRelevantLegislationNEGSAndNAGS/TheNationalAdministrationGuidelinesNAGs.aspx

Ministry of Education. (2008c). Nurturing gifted and talented children: A parentteacher-partnership. Wellington, New Zealand: Learning Media.

Ministry of Education. (2012). Gifted and talented students: Meeting their needs in New Zealand schools. Wellington, New Zealand: Learning Media.

Ministry of Social Development. (2010). The Social Report: Indicators of social wellbeing in New Zealand. Wellington, New Zealand: Author.

Moltzen, R. (2005). Realising potential: Investigating the life stories of gifted New Zealand adults. Unpublished doctoral thesis, University of Waikato, Hamilton, New Zealand.

Moltzen, R. (2011). Historical perspectives. In R. Moltzen (Ed.), Gifted and talented: New Zealand perspectives ( $3^{\text {rd }}$ ed., pp. 1-30). Auckland, New Zealand: Pearson Education.

Morales, E. E. (2010). Linking strengths: Identifying and exploring protective factor clusters in academically resilient low-socioeconomic urban students of colour. Roeper Review, 32, 164-175.

Mueller, C. E. (2009). Protective factors as barriers to depression in gifted and nongifted adolescents. Gifted Child Quarterly, 53(1), 3-14.

Neihart, M., Reis, S. M., Robinson, N., Moon, S. (Eds.) (2002). The social and emotional development of gifted children: What do we know? Waco, TX: Prufrock Press.

O’Brien, M., Claire Dale, M., St. John, S. (2011). Child poverty and inequality. In M. Claire Dale, M. O’Brien, \& S. St. John (Eds). Left further behind: How policies fail the poorest children in New Zealand. Auckland, New Zealand: Child Poverty Action Group. 
Office of the Children's Commissioner. (2012). Solutions to child poverty in New Zealand: Issues and options paper for consultation. Wellington, New Zealand: Author.

Organisation for Economic Co-operation and Development. (2011). Against the odds: Disadvantaged students who succeed in school. Retrieved from http://www.oecd.org/pisa/pisaproducts/pisa2006/47092225.pdf

Organisation for Economic Cooperation and Development. (2015). OECD Economic surveys New Zealand. Paris: OECD Publishing.

Parkyn, G. (1948). Children of high intelligence: A New Zealand study. Wellington, New Zealand: New Zealand Council for Educational Research.

Perry, B. (2014). Household incomes in New Zealand: Trends in indicators of inequality and hardship 1982 to 2013.Wellington: Ministry of Social Development.

Pfeiffer, S. I., \& Stocking, V. B. (2000). Vulnerabilities of academically gifted students. Special Services in the Schools, 16(1/2), 83-93.

Pianta, R. C., \& Walsh, D. J. (1998). Applying the construct of resilience in schools: Cautions from a developmental systems perspective. School Psychology Review, 27, 407-417.

Piirto, J. (2007). Talented children and adults: Their development and education ( $3^{\text {rd }}$ ed.). Waco, Texas: Prufrock Press.

Prom-Jackson, S., Johnson, S. T., Wallace, M. B. (1987). Home environment, talented minority youth, and school achievement. In The Journal of Negro Education, 56(1), 111-121.

Pungello, E. P., Kupersmidt, J. B., Burchinal, M. R., Patterson, C. J. (1996). Environmental risk factors and children's achievement from middle childhood to early adolescence. Developmental Psychology, 32(4), 775-767.

Reid, K., Flowers, P., Larkin, M. (2005). Exploring lived experience: An introduction to interpretative phenomenological analysis. Psychologist 18, 20-23.

Reis, S. M., Colbert, R. D., Hébert, T. P. (2005). Understanding resilience in diverse, talented students in an urban high school. Roeper Review, 27(2), 110-120.

Renzulli, J. S. (2003). Conception of giftedness and its relationship to the development of social capital. In N. Colangelo \& G. A. Davis (Eds.), Handbook of gifted education ( ${ }^{\text {rd }}$ ed., pp.75-87). Boston, MA: Pearson Education.

Riley, T. (2004). Looking ahead: Research to inform practice in the education of gifted and talented students in New Zealand.: The New Zealand Journal of Gifted Education 14(1). Retrieved from http://www.giftedchildren.org.nz/apex/v14no1art01.php

Roe, A. (1952). The making of a scientist. Westport, CT: Greenwood Press.

Rutter, M. (1987). Psychosocial resilience and protective mechanisms. American Journal of Orthopsychiatry, 57, 316-331.

Rutter, M. (2007). Resilience, competence and coping. Child Abuse and Neglect, 31, 205-209.

Schoon, I., Parsons, S., Sacker, A. (2004). Socioeconomic adversity, educational resilience, and subsequent levels of adult adaptation. Journal of Adolescent Research, 19(4), 383-404.

Seeley, K. (2003). High risk gifted learners. In N. Colangelo \& G. A. Davis (Eds.), Handbook of gifted education ( $3^{\text {rd }}$ ed., pp. 444-451). Boston, MA: Allyn \& Bacon.

Shavinina, L. (Ed.) (2009). International handbook on giftedness. New York: Springer.

Shumow, L. (1997). Daily experiences and adjustment of gifted low-income urban children at home and school. Roeper Review, 20(1), 35-38. 
Simonton, D. K. (2005). Genetics of giftedness: The implications of an emergenicepigenetic model. In R. J. Sternberg \& J. E Davidson (Eds.), Conceptions of giftedness ( $2^{\text {nd }}$ ed., pp.312-326). New York: Cambridge University Press.

Simpson, J., Duncanson, M., Oben, G., Wicken, A., Gallagher S. (2016). Child poverty monitor 2015: Technical report. Dunedin: NZ Child \& Youth Epidemiology Service, University of Otago.

Smith, J. A. (2004). Reflecting on the development of interpretative phenomenological analysis and its contribution to qualitative research in psychology. Qualitative Research Psychology, 1, 39-54.

Smith, S. (2001). J. K. Rowling: A biography. London: Michael O’Mara Books.

Smith, J. A., \& Dunworth, F. (2003). Qualitative methods in the study of development. In K. Connolly \& J. Valsiner (Eds.), The handbook of developmental psychology (pp. 603-621). London, UK: Sage.

Smith, J. A., \& Osborn, M. (2008). Interpretative phenomenological analysis. In J. A. Smith (Ed.), Qualitative psychology: A practical guide to research methods ( $2^{\text {nd }}$ ed., pp. 53-80). London: Sage.

St. John, S., \& Wynd, D. (2008). Growing inequality and child poverty. In S. St. John \& D. Wynd (Eds.), Left behind: How social and income inequalities damage New Zealand children (pp.12-26). Auckland, NZ: Child Poverty Action Group.

Stewart, R. E., \& Porath, M. (1999). From childhood rags to adult riches. High Ability Studies, 10(2), 197-211.

Tannenbaum, A. J. (2003). Nature and nurture of giftedness. In N. Colangelo \& G. A Davis (Eds.), Handbook of gifted education (3rd ed., pp. 45-59). Boston, MA: Pearson Education.

VanTassel-Baska, J. (1989). The role of the family in the success of the disadvantaged gifted learners. Journal for the Education of the Gifted, 1, 22-36.

Werner, E. E. (1993). Risk, resilience, and recovery: Perspectives from the Kauai longitudinal study. Development and Psychopathology, 5(4), 502-515.

Werner, E. E. (2000). Protective factors and individual resilience. In J. P. Shonkoff \& S. J. Meisels (Eds.), Handbook of early childhood intervention (2 ${ }^{\text {nd }}$ ed., pp.115-132). New York: Cambridge University Press.

Werner, E. E., \& Smith, R. (1982). Vulnerable but invincible: A longitudinal study of resilient children and youth. New York: McGraw Hill.

Wilkinson, R., \& Pickett, K. (2010). The spirit level: Why equality is better for everyone. London: Penguin Books.

Wynd, D. (2011). Hunger for learning: Nutritional barriers to children's education. Auckland, New Zealand: Child Poverty Action Group.

Yardley, L. (2008). Demonstrating validity in qualitative psychology. In J. Smith (Ed.), Qualitative psychology: A practical guide to research methods ( $2^{\text {nd }}$ ed., pp. 235251). London: Sage. 